\title{
Fatty acid profile differs between organic and conventionally produced cow milk independent of season or milking time
}

\author{
B. H. Schwendel, ${ }^{1}$ P. C. H. Morel, $†$ T. J. Wester, $†$ M. H. Tavendale, ${ }^{\star}$ C. Deadman, $\ddagger$ B. Fong, $\ddagger$ N. M. Shadbolt, $\dagger$ \\ A. Thatcher, $†$ and D. E. Otter* \\ ${ }^{*}$ AgResearch Grasslands Research Centre, Tennent Drive, Palmerston North 4442, New Zealand \\ †Massey University, Tennent Drive, Palmerston North 4474, New Zealand \\ ‡Fonterra Research Centre Palmerston North, Dairy Farm Road, Palmerston North 4474, New Zealand
}

\section{ABSTRACT}

Differing amounts of fresh forage and concentrates fed, and level of input contributes to the differences reported in fatty acid (FA) composition of organic and conventionally produced cow milk. In many previous studies designed to investigate this phenomenon, comparisons were made between grazed organic cows and housed conventional cows. In the present study, we have investigated differences between organic and conventional milk produced using year-round pasture grazing, as practiced in New Zealand. The FA composition was determined in milk sampled at morning and evening milking in both spring and autumn. Samples were taken from 45 cows from the Massey University organic herd and compared with 50 cows from the corresponding conventional herd grazed and managed similarly at the same location. Forty-three out of 51 analyzed FA were influenced by season, whereas 28 were different between production systems. In addition, one-half were also different due to time of milking. Levels of linoleic acid and $\alpha$-linolenic acid were higher in organic milk, whereas conjugated linoleic acid (CLA) and vaccenic acid were higher in conventional milk. The first $3 \mathrm{FA}$ (linoleic acid, $\alpha$-linolenic acid, and CLA) were more abundant in milk harvested during autumn, and the CLA concentration was also significantly influenced by time of milking. Our results confirm reports that the FA profile is affected by season and time of milking, and we also showed an effect due to the production system, when both sets of cows were kept continuously on pasture, even after taking milking time and seasonal effect into account.

Key words: milk, fatty acid, organic, milking time

Received May 4, 2014.

Accepted November 27, 2014.

${ }^{1}$ Corresponding author: Heike.Schwendel@AgResearch.co.nz

\section{INTRODUCTION}

Milk contains approximately 400 different FA, which makes it the most complex natural fat system (Lindmark Månsson, 2008). The FA profile in cow milk is influenced by diet, with variations predominantly caused by differing amounts of fresh forage and concentrates eaten (Croissant et al., 2007; Coppa et al., 2013). Other factors reported to influence the FA profile of milk include differences within and between breed (Soyeurt et al., 2008; Maurice-Van Eijndhoven et al., 2011), season (Heck et al., 2009), climate (Kamleh et al., 2010), stage of lactation (Craninx et al., 2008), and management (Fall et al., 2008). Any of those factors, as well as the interactions between them, might contribute to the concentration of individual FA in milk, with many of the mechanisms behind those effects not fully understood. Consequently, when attempting to study the effect of one specific factor (e.g., diet) on milk FA profile, it is necessary to eliminate, or to account for and control, other potential influences. Estimations of the differences between the FA composition of milk from organic and conventional farming systems are compromised in that many studies investigating the compositional disparities between organic and conventionally produced milk have not considered or been able to control factors that could have resulted in, or contributed to, such differences (e.g., diet, breed, and so on). Consequently, differences were attributed solely to the effect of the farming system. Many studies to date reporting differences between organic and conventionally produced milk have not used similar diets. It has to be acknowledged that this factor is most likely to differ between these systems. This demonstrates the difficulty when comparing data from organic and conventional farm data, because the factors that constitute the differences between the systems are, in most countries, irrevocable components of the systems. On the other hand, studies investigating the effect of diet did not consider the possible effect of the farming system (organic vs. conventional). Additionally, comparisons among stud- 
ies are problematic because it is difficult to account for any number of variables, including sampling conditions, inherent differences in farming systems among regions, levels of inputs, and even regulatory differences in conventional and organic production among countries. This may explain the differences in quantity for individual FA in and between systems as reported in different studies comparing organic and conventionally produced milk (Ellis et al., 2006; Collomb et al., 2008; Slots et al., 2009). A study with multiple side-by-side organic versus conventionally managed pasture-based herds observed over several years would be desirable to account variation within each system at different locations and climatic conditions. In practice, however, it has not been possible to identify several farms that would be able to exclude the variety of influence factors we were able to exclude in our study.

The aim of the present study was to determine whether differences are present in FA composition between organic and conventional cow milk produced in an all-year-round pasture grazing system as commonly used in New Zealand.

\section{MATERIALS AND METHODS}

\section{Farm and Herd Data}

During the 2010 to 2011 milking season, milk samples were collected from individual cows of one organic (45 cows) and one conventional herd (50 cows) at Massey
University, Palmerston North, New Zealand (Kelly et al., 2005). Both herds were derived from a single herd, which was divided in 2001 after taking breeding value, production value, somatic cell count, age, and parity of each individual animal into account to create 2 matching herds. Characteristics of both farms and herds during the 2010 to 2011 milking season are averaged over the milking season and listed in Table 1, with animal data originating from monthly herd testing. Milking was conducted at $0600 \mathrm{~h}$ in the morning and $1400 \mathrm{~h}$ in the afternoon, with cows given access to new pasture after each milking event. Daylight hours were from 0544 to $2033 \mathrm{~h}$, and from 0714 to $1947 \mathrm{~h}$ in spring and autumn, respectively. The amount of pasture available for each cow before milk sample collection in spring was 9.0 and $9.3 \mathrm{~kg}$ of DM for conventional and 11.8 and $11.8 \mathrm{~kg}$ of DM for organic cows, in the morning and afternoon, respectively. In autumn, the amount of pasture available was 8.1 and $8.1 \mathrm{~kg}$ of DM for conventional and 11.4 and $8.7 \mathrm{~kg}$ of DM for organic cows in the morning and afternoon, respectively.

A cider vinegar-garlic mixture (Dairy-Mate Direct Health Products Ltd., Nelson, New Zealand) was added daily to the water trough of organic cows, as a food supplement and natural antibiotic (Ozturk et al., 2009). This resulted in an estimated consumption of $10 \mathrm{mg}$ of garlic oil per cow per day. Additionally, during late spring and early summer (October-December), organic cows were drenched daily with approximately $18 \mathrm{~g}$ (20 $\mathrm{mL}$ ) of fish oil (BioSea Ltd., Nelson, New Zealand), to

Table 1. Farm and animal characteristics averaged over lactation period for organic and conventional herds

\begin{tabular}{|c|c|c|}
\hline Item & Organic & Conventional \\
\hline \multicolumn{3}{|l|}{ Farm factor } \\
\hline Number of cows & 45 & 50 \\
\hline Stocking rate cow/ha & 2.2 & 2.4 \\
\hline $\mathrm{N}$ fertilizer application, $\mathrm{kg} / \mathrm{ha}$ & 14.7 organic fertilizer $^{1}$ & $\begin{array}{l}123.0 \text { urea, } \\
\text { ammonium sulfate }\end{array}$ \\
\hline Herbage yield, t of DM/ha & 10.4 & 11.4 \\
\hline \multicolumn{3}{|l|}{ Animal factor } \\
\hline \multicolumn{3}{|l|}{ Breed, ${ }^{2} \%$} \\
\hline Friesian & 56.1 & 77.7 \\
\hline Jersey & 40.2 & 21.0 \\
\hline Ayrshire & 1.1 & \\
\hline $\begin{array}{l}\text { Mean days in lactation at sampling in spring/ } \\
\text { autumn }\end{array}$ & $90 / 202$ & $100 / 212$ \\
\hline Mean breeding worth ${ }^{3}$ & 79 & 94 \\
\hline Mean production value & 95 & 112 \\
\hline Mean age, yr & 3.7 & 4.0 \\
\hline Mean milk volume, $\mathrm{L} /$ cow per day & 17.2 & 17.8 \\
\hline Mean milk protein, $\%$ & 3.67 & 3.60 \\
\hline Mean milk fat, $\%$ & 5.53 & 5.00 \\
\hline Mean $\mathrm{SCC}, \times 1,000$ cells $/ \mathrm{mL}$ & 163.1 & 151.6 \\
\hline
\end{tabular}

${ }^{1}$ Osflo Fertilizer Ltd., New Plymouth, New Zealand.

${ }^{2}$ Average blood blend of the herd.

${ }^{3}$ New Zealand ranks dairy cows by their expected ability to breed high merit replacements, described as breeding worth. 
Table 2. Measured chemical composition of organic and conventional pasture ${ }^{1}$

\begin{tabular}{lcccc}
\hline Item & $\begin{array}{c}\text { Organic } \\
(\mathrm{n}=7)\end{array}$ & $\begin{array}{c}\text { Conventional } \\
(\mathrm{n}=7)\end{array}$ & $\mathrm{SE}$ & $P$-value \\
\hline $\mathrm{DM}, \%$ & 21.6 & 19.3 & 2.7 & $\mathrm{NS}$ \\
CP, \% of DM & 20.8 & 22.2 & 1.8 & $\mathrm{NS}$ \\
Lipid, \% of DM & 3.3 & 3.7 & 0.3 & $\mathrm{NS}$ \\
Ash, \% of DM & 9.4 & 9.5 & 0.7 & $\mathrm{NS}$ \\
NDF, \% of DM & 47.1 & 46.4 & 1.4 & NS \\
Soluble sugars and starches, \% of DM & 11.3 & 12.1 & 1.8 & NS \\
ME, MJ/kg of DM & 11.8 & 12.0 & 0.3 & NS \\
\hline
\end{tabular}

${ }^{1}$ Analysis was undertaken by: feedTECH AgResearch (Palmerston North, New Zealand) via NIRS, with samples $(\mathrm{n}=7)$ collected between July 2010 and March 2011.

NS: $P>0.1$.

influence the oestrous cycle and as a bloat preventative agent. Conventional cows were treated with antibiotics and oxytocin when necessary, which are not approved by the International Foundation for Organic Agriculture. Both herds were grazed and managed similarly on different paddocks at adjacent locations under the same management, which was representative of organic and conventional dairy herds for this geographical area in New Zealand. No supplemental feed was provided to either herd in the $6 \mathrm{wk}$ leading up to and on the day of sampling, with pasture growth being sufficient to feed the animals.

Botanical composition of pasture from both farms was analyzed twice throughout the 2010 to 2011 milking season (Figure 1). For this purpose, pasture samples were taken from 10 paddocks of each farm. Chemical composition was analyzed from pasture samples from 6 paddocks of each farm, 7 times between August 2010 and May 2011 (Table 2).

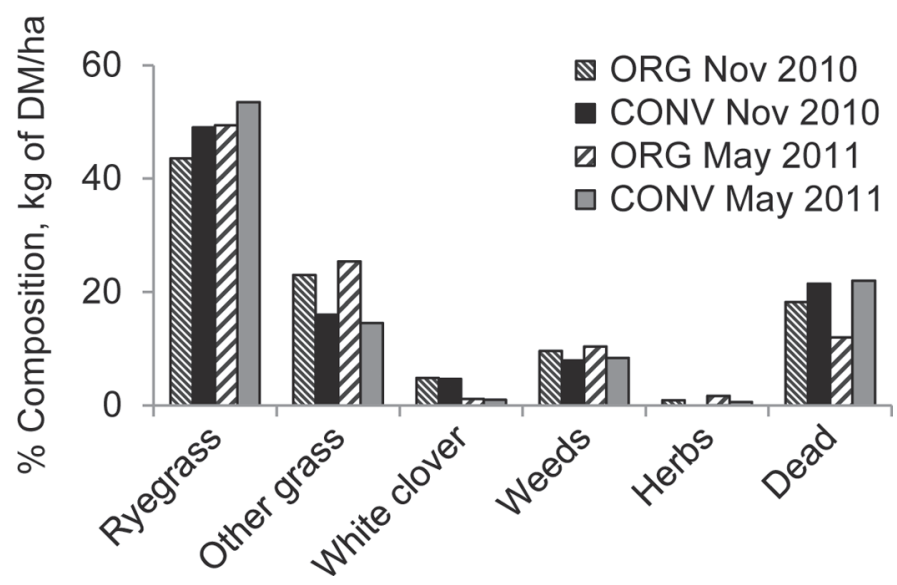

Figure 1. Botanical composition of organic (ORG) and conventional (CONV) pasture in spring (November; Nov) and autumn (May).

\section{Sampling and Sample Treatment}

Four milk samples each were taken from 45 organic and 50 conventional cows. One sample each from morning and afternoon milking was collected during $1 \mathrm{~d}$ in New Zealand spring (November 2010) and $1 \mathrm{~d}$ in New Zealand autumn (March 2011). Samples were taken from the milking line during the routine milking process in 100-mL plastic screw-top containers and stored at $-20^{\circ} \mathrm{C}$ until analysis.

\section{FA Analyses}

The extraction and methylation process described by Toledo et al. (2002) was adjusted to a smaller sample amount of $1 \mathrm{~mL}$. Samples were extracted with $2 \mathrm{~mL}$ of 2-propanol and $1.5 \mathrm{~mL}$ of hexane, which contained $\left[1,1,1-{ }^{13} \mathrm{C}\right]$ Trioctanoin (Larodan Fine Chemicals, Solna, Sweden) as an internal standard. The hexane layer was dried under $\mathrm{N}_{2}$ and the milk fat was dissolved in $1 \mathrm{~mL}$ of hexane before the addition of $2 \mathrm{~mL}$ of $0.1 M \mathrm{KOH}$ in methanol. Tubes were sealed and heated for $1 \mathrm{~h}$ at $50{ }^{\circ} \mathrm{C}$, to facilitate the trans-esterification process of glycerides into the corresponding FAME. The resulting alkali mixture was neutralised with $0.1 \mathrm{M}$ $\mathrm{HCl}$. The organic solvent layer containing FAME was diluted 1:1 (vol:vol) with hexane and then injected into a GC-MS (Shimadzu GC-17A QP5050A, Shimadzu, Kyoto, Japan).

The FAME were separated on a $60 \mathrm{~m}$ SGE BPX70 column (ID $0.25 \mathrm{~mm}$; film thickness $0.25 \mu \mathrm{m}$ ) with a 60 min run time. Injection port and interface temperatures were maintained at $240^{\circ} \mathrm{C}$. Column temperature profile was as follows: held at $50^{\circ} \mathrm{C}$ for $5 \mathrm{~min}$, increased at $12.5^{\circ} \mathrm{C} / \mathrm{min}$ to $170^{\circ} \mathrm{C}$, increased at $1.0^{\circ} \mathrm{C} / \mathrm{min}$ to $193^{\circ} \mathrm{C}$, increased at $4.0^{\circ} \mathrm{C} / \mathrm{min}$ to $240^{\circ} \mathrm{C}$, and held for $8 \mathrm{~min}$ at $240^{\circ} \mathrm{C}$. An inlet pressure of $180 \mathrm{kPa}$ resulted in a column flow of $1.7 \mathrm{~mL} / \mathrm{min}$, with helium used as the carrier gas. The mass spectrometer was used in selected ion mode and acquired data for masses 55, 67, 74, 75, and $79 \mathrm{~m} / \mathrm{z}$. 
Fifty-one FAME were identified through retention time, external standard (Supelco FAME Mix C4-C24; Sigma-Aldrich, St. Louis, MO), and intensity ratios of acquired ions to the base ion. The latter confirmed the degree of saturation of each individual FA (Härtig, 2008). Internal standard was identified using the base ion $75 \mathrm{~m} / \mathrm{z}$. Results were calculated via crossmultiplication taking into account the peak areas of the external standard and sample FA, and the mass of the external standard for the FA concerned. Fatty acids not included in the external standard mixture were calculated using standard FA with identical chain length (e.g., C18:1 t11 was calculated using area and mass of C18:1 t9). All FA are expressed as grams of FA per $100 \mathrm{~g}$ of $\mathrm{FA}$.

\section{Statistical Analyses}

Data on the composition of pasture were analyzed by use of ANOVA using a general linear model in SAS (9.3) with system as fixed and date as random effects. Data for FA were tested for normality and outliers, and statistically explored, to test for a difference between the group means, through ANOVA using a mixed model. It included fixed effects of system (organic versus conventional), sampling date (spring versus autumn) and sampling time [morning (AM) versus afternoon (PM)], as well as their interactions, whereas cow within system was a random effect. An F-test was used to ascertain the degree of differences, and a multiple range test to compare the interaction combinations. The data set was further explored with principal component analysis (PCA) and discriminant function analysis. Discriminant function analysis is used to predict group membership of a sample into one of several naturally occurring groups. The prediction is based on linear combination of variables which discriminate between groups. In our trial, 17 FA (variables) were selected by having been identified as the best predictors of whether or not a milk sample belonged to a specific milking event, depending on system, season, and time of milking.

\section{RESULTS AND DISCUSSION}

The results from the ANOVA showed a variety of differences between milk samples. These were possibly caused by several factors, which are discussed below.

\section{System Effect}

Twenty-eight of the $51 \mathrm{FA}$ analyzed showed different concentrations $(P<0.001)$ between organic and conventional milk samples (Table 3). Butyric acid (C4:0), stearic acid (C18:0, $P<0.01)$, linoleic acid (C18:2 cis-9,12; LnA), and $\alpha$-linolenic acid (C18:3 cis-9,12,15; ALA) were higher in organic milk, whereas conventional milk contained a greater amount of odd- and branched-chain FA (OBCFA), as well as vaccenic acid (C18:1 trans-11; VA) and CLA (C18:2 cis-9,trans-11). These differences between organic and conventionally produced milk were observed even though cows from both herds were fed solely on pasture of similar species diversity, and similar botanical (Figure 1) and chemical composition (Table 2). Paddocks for the conventional herd had a larger proportion of ryegrass and dead material, whereas those for the organic herd contained a higher amount of other grasses, weeds, and herbs. The clover distribution in the paddocks was similarly low for both treatments with a seasonal variation, resulting in 4.8 and $4.7 \%$ DM of pasture cover in November 2010 and 1.1 and 1.0\% in May 2011 for organic and conventional pasture, respectively. Organic pasture contained a higher amount of herbs, including plantain, and other grasses (1.3 and $23.8 \% \mathrm{DM}$ ) compared with conventional pastures ( 0.3 and $15.2 \% \mathrm{DM})$. Although the herb content differed between the pastures, it was very low for both. The organic herd also had a larger amount of total pasture available per cow, $20.8 \mathrm{~kg}$ of DM/d compared with $16.4 \mathrm{~kg}$ of $\mathrm{DM} / \mathrm{d}$ for conventional cows. None of the chemical compounds measured showed a significant difference between organic and conventional pastures. Conventional pastures produced about $10 \%$ more DM per hectare than organic pastures while receiving an approximately 9 times higher application of $\mathrm{N}$ fertilizer.

The limited number of studies conducted in a setting comparable to our trial limits possible comparisons and subsequent conclusions about the causes for the differences between the FA profile of organic and conventional milk in a low input (LI) farming system.

Differences in milk FA composition have been reported previously when comparing milk from LI organic versus LI conventional dairy farms. The farming system described by Butler et al. (2009) was comparable to the present study, with the 2 sets of farms practicing spring block calving and an average of over $90 \%$ of the diet DM coming from grazing. Milk from LI conventional farms had, similar to our results, higher amounts of VA and CLA, whereas no difference between milk varieties was reported for LnA and ALA. Butler et al. (2009) assumed that those differences were related to higher dietary intake of LnA by LI conventional cows caused by differences in sward composition. In contrast, Collomb et al. (2008) studied milk fat composition from organic and integrated dairy farms and found higher amounts of VA, ALA, CLA, and branched-chain FA in organic milk. These differences were attributed to the higher amounts of grasses (87 and $83 \%$ of total DMI 
Table 3. Effect of system, season, and time of milking on FA

\begin{tabular}{|c|c|c|c|c|c|c|c|c|c|c|c|c|c|c|c|c|}
\hline \multirow[b]{2}{*}{$\begin{array}{l}\mathrm{FA}^{1} \\
(\mathrm{~g} / 100 \mathrm{~g} \text { of } \mathrm{FA})\end{array}$} & \multicolumn{2}{|c|}{ System } & \multirow[b]{2}{*}{$\mathrm{SED}^{3}$} & \multicolumn{2}{|c|}{ Season } & \multirow[b]{2}{*}{ SED } & \multicolumn{2}{|c|}{ Time of milking } & \multirow[b]{2}{*}{ SED } & \multicolumn{7}{|c|}{$P$-value } \\
\hline & Conv $^{2}$ & Organic & & Spring & Autumn & & $\mathrm{AM}$ & PM & & System & Season & Time & $\mathrm{T} \times \mathrm{S}^{4}$ & Sys $\times \mathrm{S}^{5}$ & $\begin{array}{l}\text { Sys } \times \\
\mathrm{T}^{6}\end{array}$ & $\begin{aligned} \text { Sys } & \times \mathrm{T} \\
\times & \mathrm{S}^{7}\end{aligned}$ \\
\hline \multicolumn{17}{|l|}{ Even-chain SFA } \\
\hline $\mathrm{C} 4: 0$ & 2.11 & 2.30 & 0.040 & 2.07 & 2.34 & 0.034 & 2.29 & 2.11 & 0.034 & $* * *$ & $* * *$ & $* * *$ & NS & $* * *$ & NS & NS \\
\hline C6:0 & 1.69 & 1.78 & 0.027 & 1.74 & 1.74 & 0.020 & 1.79 & 1.68 & 0.020 & $* *$ & NS & $* * *$ & *** & $* * *$ & NS & $\dagger$ \\
\hline $\mathrm{C} 8: 0$ & 1.18 & 1.18 & 0.019 & 1.24 & 1.13 & 0.012 & 1.22 & 1.14 & 0.012 & NS & $* * *$ & $* * *$ & *** & $* * *$ & NS & NS \\
\hline C10:0 & 2.67 & 2.69 & 0.063 & 2.93 & 2.43 & 0.029 & 2.74 & 2.61 & 0.029 & NS & $* * *$ & $* * *$ & $* * *$ & $* * *$ & ** & NS \\
\hline C12:0 & 3.22 & 3.20 & 0.084 & 3.49 & 2.92 & 0.036 & 3.27 & 3.15 & 0.036 & NS & $* * *$ & $* *$ & $* * *$ & $* * *$ & * & NS \\
\hline C14:0 & 11.32 & 11.29 & 0.177 & 11.87 & 10.73 & 0.097 & 11.42 & 11.19 & 0.096 & NS & $* * *$ & $*$ & $* * *$ & $*$ & $* * *$ & NS \\
\hline C16:0 & 31.53 & 32.79 & 0.527 & 31.54 & 32.79 & 0.261 & 32.80 & 31.53 & 0.260 & $*$ & $* * *$ & $* * *$ & $* * *$ & NS & NS & $* * *$ \\
\hline C18:0 & 9.56 & 10.47 & 0.302 & 10.82 & 9.22 & 0.150 & 9.78 & 10.26 & 0.150 & $* *$ & $* * *$ & $* *$ & NS & $* * *$ & $\dagger$ & NS \\
\hline $\mathrm{C} 20: 0$ & 0.091 & 0.104 & 0.0036 & 0.091 & 0.105 & 0.0025 & 0.099 & 0.097 & 0.0026 & $* * *$ & $* * *$ & NS & $* * *$ & $* * *$ & $* * *$ & $t$ \\
\hline $\mathrm{C} 22: 0$ & 0.031 & 0.035 & 0.0015 & 0.030 & 0.037 & 0.0010 & 0.033 & 0.033 & 0.0010 & $* *$ & $* * *$ & NS & $* * *$ & $\dagger$ & $* * *$ & NS \\
\hline $\mathrm{C} 24: 0$ & 0.020 & 0.022 & 0.0009 & 0.020 & 0.022 & 0.0006 & 0.020 & 0.021 & 0.0007 & $\dagger$ & $* * *$ & NS & $* * *$ & NS & $* * *$ & $* * *$ \\
\hline \multicolumn{17}{|l|}{ Odd-chain SFA } \\
\hline $\mathrm{C} 7: 0$ & 0.021 & 0.016 & 0.0008 & 0.019 & 0.018 & 0.0005 & 0.020 & 0.017 & 0.0005 & $* * *$ & $* *$ & $* * *$ & NS & $* * *$ & * & $* * *$ \\
\hline C9:0 & 0.023 & 0.019 & 0.0010 & 0.022 & 0.020 & 0.0005 & 0.022 & 0.021 & 0.0005 & $* * *$ & $* * *$ & $*$ & $*$ & $* *$ & * & NS \\
\hline C11:0 & 0.041 & 0.034 & 0.0020 & 0.042 & 0.033 & 0.0009 & 0.038 & 0.037 & 0.0009 & $* * *$ & $* * *$ & NS & $* *$ & ** & * & $* *$ \\
\hline C13:0 & 0.077 & 0.062 & 0.0023 & 0.073 & 0.066 & 0.0012 & 0.069 & 0.070 & 0.0012 & $* * *$ & $* * *$ & NS & $* *$ & $\dagger$ & $* * *$ & NS \\
\hline C15:0 & 1.319 & 1.138 & 0.0213 & 1.189 & 1.268 & 0.0114 & 1.190 & 1.267 & 0.0114 & $* * *$ & $* * *$ & $* * *$ & $* * *$ & $*$ & $* * *$ & NS \\
\hline $\mathrm{C} 17: 0$ & 0.578 & 0.566 & 0.0092 & 0.615 & 0.519 & 0.0058 & 0.551 & 0.593 & 0.0058 & NS & $* * *$ & $* * *$ & $* *$ & $* * *$ & $* * *$ & NS \\
\hline $\mathrm{C} 21: 0$ & 0.017 & 0.021 & 0.0009 & 0.018 & 0.020 & 0.0005 & 0.018 & 0.020 & 0.0005 & $* * *$ & $* * *$ & $* * *$ & $* *$ & $*$ & $* * *$ & $*$ \\
\hline $\mathrm{C} 23: 0$ & 0.0014 & 0.0018 & 0.00008 & 0.0017 & 0.0016 & 0.0001 & 0.0016 & 0.0018 & 0.00007 & $* * *$ & NS & $* *$ & $* * *$ & $* * *$ & $* * *$ & ** \\
\hline $\mathrm{C} 25: 0$ & 0.016 & 0.016 & 0.0007 & 0.016 & 0.016 & 0.0003 & 0.015 & 0.017 & 0.0003 & NS & NS & $* * *$ & $* * *$ & NS & $* *$ & $* * *$ \\
\hline \multicolumn{17}{|l|}{ Branched-chain FA } \\
\hline $\mathrm{C} 13: 0$ iso & 0.032 & 0.028 & 0.0007 & 0.027 & 0.034 & 0.0005 & 0.030 & 0.031 & 0.0005 & $* * *$ & $* * *$ & $*$ & NS & $* * *$ & $* * *$ & $* *$ \\
\hline $\mathrm{C} 14: 0$ iso & 0.103 & 0.081 & 0.0021 & 0.090 & 0.095 & 0.0010 & 0.088 & 0.097 & 0.0010 & $* * *$ & $* * *$ & $* * *$ & $*$ & $* * *$ & $* * *$ & $* *$ \\
\hline $\mathrm{C} 15: 0$ iso & 0.409 & 0.317 & 0.0107 & 0.386 & 0.341 & 0.0046 & 0.339 & 0.388 & 0.0046 & $* * *$ & $* * *$ & $* * *$ & $* * *$ & $\dagger$ & $* * *$ & NS \\
\hline C15:0 anteiso & 0.478 & 0.381 & 0.0152 & 0.483 & 0.375 & 0.0094 & 0.468 & 0.390 & 0.0094 & $* * *$ & *** & $* * *$ & $* * *$ & NS & NS & NS \\
\hline C16:0 iso & 0.184 & 0.156 & 0.0034 & 0.177 & 0.162 & 0.0022 & 0.161 & 0.178 & 0.0021 & $* * *$ & $* * *$ & $* * *$ & NS & NS & NS & $\dagger$ \\
\hline $\mathrm{C} 17: 0$ iso & 0.331 & 0.288 & 0.0073 & 0.268 & 0.351 & 0.0043 & 0.284 & 0.334 & 0.0043 & $* * *$ & $* * *$ & $* * *$ & $* * *$ & NS & $* * *$ & NS \\
\hline $\mathrm{C} 17: 0$ anteiso & 0.355 & 0.336 & 0.0057 & 0.365 & 0.326 & 0.0036 & 0.327 & 0.365 & 0.0036 & $* *$ & $* * *$ & $* * *$ & $* * *$ & NS & NS & $* * *$ \\
\hline $\mathrm{C} 18: 0$ iso & 0.030 & 0.028 & 0.0008 & 0.031 & 0.027 & 0.0006 & 0.028 & 0.030 & 0.0006 & $*$ & $* * *$ & $* *$ & $*$ & $* * *$ & $* * *$ & NS \\
\hline \multicolumn{17}{|l|}{ MUFA } \\
\hline $\mathrm{C} 10: 1$ & 0.22 & 0.20 & 0.006 & 0.20 & 0.22 & 0.003 & 0.21 & 0.21 & 0.003 & $* * *$ & *** & $\dagger$ & $* * *$ & $* * *$ & NS & NS \\
\hline C14:1 c9 & 1.15 & 0.99 & 0.042 & 0.95 & 1.19 & 0.015 & 1.05 & 1.09 & 0.015 & $* * *$ & $* * *$ & $*$ & $* *$ & NS & $\dagger$ & $*$ \\
\hline C16:1 c9 & 1.47 & 1.41 & 0.053 & 1.35 & 1.54 & 0.022 & 1.37 & 1.51 & 0.021 & NS & $* * *$ & $* * *$ & $* * *$ & *** & $\dagger$ & NS \\
\hline C16:1 t9 & 0.17 & 0.18 & 0.007 & 0.20 & 0.16 & 0.006 & 0.15 & 0.21 & 0.006 & $\dagger$ & $* * *$ & $* * *$ & $* * *$ & $* * *$ & $t$ & $* * *$ \\
\hline C17:1 c9 & 0.20 & 0.18 & 0.005 & 0.18 & 0.19 & 0.003 & 0.18 & 0.20 & 0.003 & $* * *$ & $* * *$ & $* * *$ & NS & $* * *$ & $* *$ & $\dagger$ \\
\hline C18:1 c9 & 16.09 & 15.79 & 0.365 & 15.79 & 16.09 & 0.201 & 15.05 & 16.82 & 0.202 & NS & NS & $* * *$ & $* * *$ & $* * *$ & NS & NS \\
\hline C18:1 t9 & 0.21 & 0.18 & 0.007 & 0.18 & 0.22 & 0.005 & 0.20 & 0.20 & 0.005 & $* * *$ & $* * *$ & NS & NS & $\dagger$ & $* * *$ & NS \\
\hline C18:1 c11 & 0.30 & 0.26 & 0.010 & 0.28 & 0.29 & 0.005 & 0.28 & 0.29 & 0.005 & $* * *$ & $* *$ & NS & * & $* * *$ & $* * *$ & NS \\
\hline $\mathrm{C} 18: 1 \mathrm{t} 11 \mathrm{VA}$ & 4.26 & 2.59 & 0.195 & 3.50 & 3.34 & 0.066 & 3.28 & 3.57 & 0.066 & $* * *$ & * & $* * *$ & $* * *$ & NS & NS & NS \\
\hline \multirow{2}{*}{\multicolumn{17}{|c|}{ PUFA }} \\
\hline & & & & & & & & & & & & & & & & \\
\hline $\mathrm{C} 18: 2$ t9,12 & 0.688 & 0.747 & 0.0210 & 0.681 & 0.753 & 0.0155 & 0.685 & 0.750 & 0.0158 & $* * *$ & $* * *$ & $* * *$ & * & $* * *$ & * & NS \\
\hline C18:2 c9,12 LnA & 0.814 & 0.909 & 0.0221 & 0.744 & 0.980 & 0.0177 & 0.863 & 0.861 & 0.0180 & $* * *$ & *** & NS & $* * *$ & $* * *$ & $* * *$ & NS \\
\hline C18:3 c9,12,15 ALA & 0.902 & 1.093 & 0.0339 & 0.927 & 1.068 & 0.0246 & 0.987 & 1.009 & 0.0251 & $* * *$ & $* * *$ & NS & $\dagger$ & $* * *$ & $* * *$ & $* *$ \\
\hline C18:2 c9t11 CLA & 1.582 & 0.929 & 0.1074 & 0.998 & 1.512 & 0.0760 & 1.173 & 1.338 & 0.0771 & $* *$ & $* * *$ & $* *$ & NS & $* * *$ & NS & * \\
\hline C18:2 t10t12 CLA & 0.053 & 0.046 & 0.0024 & 0.039 & 0.060 & 0.0017 & 0.050 & 0.050 & 0.0017 & $* * *$ & $* * *$ & NS & $* * *$ & $* * *$ & ** & $* * *$ \\
\hline $\mathrm{C} 20: 2$ c, c n-6 & 0.031 & 0.036 & 0.0015 & 0.029 & 0.038 & 0.0016 & 0.036 & 0.032 & 0.0016 & $* * *$ & $* * *$ & $* *$ & $* * *$ & $* * *$ & $*$ & NS \\
\hline
\end{tabular}




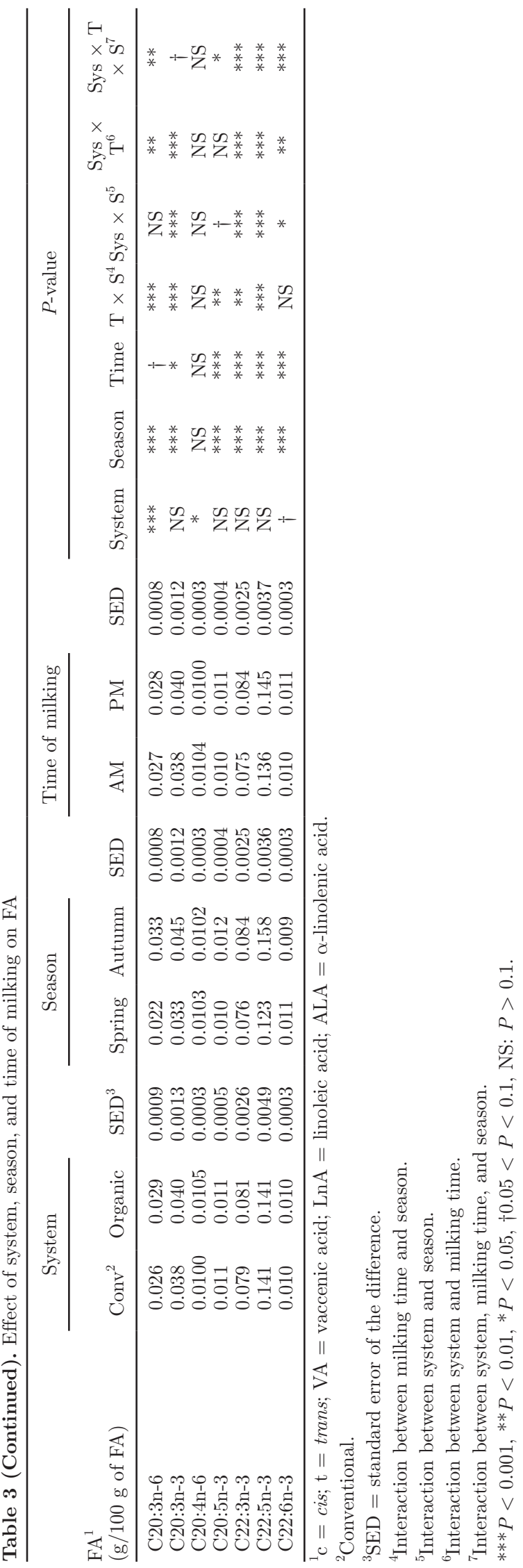

for organic and conventional, respectively) and lower amounts of concentrate in the diet of organic cows. Collomb et al. (2008) suggested organic cows developed specific rumen ecology as a consequence of the higher grass diet. Kusche et al. (2010), who compared LI biodynamic and LI conventional milk, reported no significant difference in CLA levels and higher amounts of n-3 FA in LI biodynamic milk. The latter was, similar to Collomb et al. (2008), attributed to a higher amount of fresh grass in the diet ( $81 \%$ biodynamic LI versus $58 \%$ conventional LI). Organic and conventional cows in our study had the same amount of pasture in their diets (100\%), which were similar in chemical and botanical composition, and differences in FA profile between the 2 milk types must, therefore, relate to causes other than fresh forage intake.

Although not usually mentioned, differences in fertilizer application generally can be assumed for most studies comparing organic and conventional milk from pasture grazed cows. In our study, we did not observe a difference in the proximate chemical and botanical composition of pastures, despite differences in fertilizer application rates. Consequently, the effect of fertilizer in regard to those 2 factors appears to be minimal in our study. Similar to our results, Mackle et al. (1996) reported only minimal differences in chemical composition when comparing pastures that had high (100-150 $\mathrm{kg} / \mathrm{ha}$ ) and low $(20 \mathrm{~kg} / \mathrm{ha})$ rates of $\mathrm{N}$ fertilizer applied. Despite similarity between the chemical composition of pastures, Mackle et al. (1996) reported higher rumen $\mathrm{pH}$ in cows fed on high N-pasture, which could affect rumen ecology, and consequently could alter the rate of biohydrogenation of unsaturated FA.

Similarity in proximate chemical composition of pastures as seen in our trial should not lead to the assumption that no other differences are present between chemical composition of the pastures. Several studies (Boufaïed et al., 2003; Elgersma et al., 2005; Arvidsson et al., 2012; Glasser et al., 2013) reported higher content of total FA and ALA after application of various N fertilizer levels (30-120 kg of N/ha) on the same forage. $\alpha$-Linolenic acid is the most abundant FA in most common pasture grasses (Dewhurst et al., 2001; Elgersma et al., 2005), representing between 60 and $70 \%$ of all FA. Elgersma et al. (2005) reported an approximate increase of $3 \mathrm{~g}$ of ALA $\mathrm{kg} / \mathrm{DM}$ in ryegrass pasture per $50 \mathrm{~kg}$ of $\mathrm{N} / \mathrm{ha}$. This would result in a significant difference in total amount of ALA taken up by cows feeding solely on fertilized pasture compared with cows feeding on pasture with lower $\mathrm{N}$ fertilizer treatment.

Up to $99 \%$ of ALA and LnA consumed by cows is biohydrogenated in the rumen, with VA being a main derivative (Lee and Jenkins, 2011). Vaccenic acid is then partly desaturated to CLA in the mammary 
gland, explaining the elevated content of VA and CLA in milk from predominantly grass-fed cows (Leiber et al., 2005; Destaillats et al., 2006). A higher dietary intake of ALA should consequently lead to a higher amount of VA and CLA in milk. This is supported by Leiber et al. (2005) who reported that lowland pasture containing almost twice as much ALA resulted in 25\% more CLA in milk than cows grazing alpine pasture. It can only be speculated if differences in FA composition existed between the 2 pastures in our trial, but other grazing studies observed similar results where VA and CLA were increased and ALA decreased in milk from cows grazing on lowland and rotational grazed pasture, respectively (Leiber et al., 2005; Coppa et al., 2011).

None of these studies mentioned fertilizer application, but this may be deduced by examining differences in plant diversity among pastures, as shown below. Leiber et al. (2005) compared the effect of lowland and alpine pasture on milk FA composition, whereas Coppa et al. (2011) studied the differences of rotational and permanent grazing on milk FA composition. Alpine pasture and permanently grazed pasture reportedly provided a higher variety in plant species compared with lowland and rotationally grazed pasture. Although this can only be speculated, alpine pasture and permanently grazed pasture might have been treated with less fertilizer, then lowland and rotationally grazed pasture, respectively, with a more diverse botanical composition as an indicator for a lesser amount of fertilizer.

Fertilizer application and its effect on the botanical composition of pastures have been studied, with results depending on the amount and type of fertilizer applied. Mackle et al. (1996) and McKenzie et al. (1999) found that clover content in pasture was not affected by $\mathrm{N}$ application (45-150 $\mathrm{kg}$ of N/ha), whereas Bolland and Guthridge (2007) and Bochi-Brum et al. (2011) reported a continuous increase in grass content with greater $\mathrm{N}$ fertilizer application $(60-320$ and $60-180 \mathrm{~kg}$ of $\mathrm{N} /$ ha, respectively). Lambert et al. (1986) reported a change in botanical composition over a 9-yr period with ryegrass continuously increasing with application of $\mathrm{P}$ fertilizer. Differences in composition with regard to clover and grass mixtures have been reported to affect FA in milk, with clover reportedly increasing the concentration of ALA in milk (Vanhatalo et al., 2007; Lourenço et al., 2008; Moorby et al., 2009).

Several studies that compared pasture-based diets (Wiking et al., 2010; Larsen et al., 2012) found that variation in botanical composition between pastures are reflected in the differences in chemical composition of the pasture, which can then affect the milk FA composition (Falchero et al., 2010; Coppa et al., 2011; Gorlier et al., 2013). Baars et al. (2012) reported greater amounts of all branched-chain FA in milk when cows were fed hay that contained a higher amount of herbaceous plant material. Herbs such as chicory (Molan et al., 2003) and plantain (Jarzomski et al., 2000) contain condensed tannins and secondary plant metabolites that are known to influence the biohydrogenation of FA in the rumen (Patra and Saxena, 2011; Petersen et al., 2011). For our study, the differences in clover and herb content between farms were considered minor and could not be statistically explored due to the lack of repetitive pasture composition measurements. Consequently, we are unable to completely exclude the possibility that slight differences in botanical composition had an effect on milk FA composition.

With only a limited number of studies focusing on intensity of the farming system (high or low input) (Coppa et al., 2013), rather than the farming style (conventional or organic), and inconsistent results for individual FA of these studies, comparing milk from LI organic and conventional dairy farms makes an explanation for our findings challenging.

Another possible cause for the differences in FA profiles in our study, as suggested by Collomb et al. (2008), may have been differences in the rumen ecology between the 2 herds. Our results show higher amounts $(P$ $<0.001$ ) for 11 OBCFA, including the most abundant ones (C15:0, C15:0 iso and anteiso) in conventionally produced milk. Changes in the OBCFA profile leaving the rumen, which are subsequently reflected in milk FA profile, are largely caused by alterations in the relative abundance of specific bacterial populations rather than by the availability of precursors for OBCFA (Vlaeminck et al., 2006; French et al., 2012). No samples of ruminal contents were taken in this trial and it was therefore not possible to assess the existence of differences in the rumen microbiota between organic and conventional farmed cows.

The drenching of the organic herd in early lactation with fish oil and the continuous supplementation with cider-vinegar garlic were not considered to have an effect on milk FA composition in our trial. This assumption is supported by the fact that all n-3 PUFA were significantly higher in autumn milk when no fish oil supplementation occurred. Studies that reported changes in milk FA profile when using fish oil generally involved administration of the oil at 1 to $3 \%$ of DMI (Donovan et al., 2000; Osborne et al., 2008; Huws et al., 2010). Fish oil contains large amounts of eicosapentaenoic acid and docosahexaenoic acid (DHA), as well as lower levels of docosapentaenoic acid (DPA), FA that can be found at higher levels in milk from supplemented cows (Bharathan et al., 2008). Moate et al. (2013) reported a linear response between increasing DPA and DHA levels in the diet and the transfer into milk, with DPA having a greater transfer coefficient. 
Organic cows had been drenched continuously for $50 \mathrm{~d}$ before the collection of the first milk sample set in November (spring). The amount of fish oil supplemented represented $0.2 \%$ of the DMI. Consequently, the fish oil amount administered to organic cows in the current trial was not considered to be sufficient to increase levels of eicosapentaenoic acid, DPA, and DHA in milk.

The lack of research on the long-term effects of chronic supplementation with small doses of garlic makes it difficult to determine the effect regular supplementation of cows with cider-vinegar garlic mix could have had in our study. Garlic is known for its antimicrobial properties (Feldberg et al., 1988) and has been reported to influence ruminal volatile FA composition (Calsamiglia et al., 2007). Recent research measuring the in vitro effect of garlic on methanogens from the rumen observed a change in the ratio of acetate, propionate, and butyrate when 30 or $300 \mathrm{mg} / \mathrm{L}$ of garlic oil was added to buffered rumen fluid (Busquet et al., 2005). The amount of garlic oil administered to the organic cows in our trial was approximately $10 \mathrm{mg} / \mathrm{d}$ and therefore far lower, given that those were added to approximately $60 \mathrm{~L}$ of rumen fluid with an approximately $8 \mathrm{~h}$ turnover rate (Woodford and Murphy, 1988). Additionally, Cardozo et al. (2004) reported that, whereas plant extracts modified ruminal fermentation, microbes adapted to some extracts after only $6 \mathrm{~d}$. It is therefore questionable if the supplementation with a vinegar-garlic mix contributed to the differences in FA profiles seen between the 2 milk varieties.

The effect of the breed in our study was also considered as a possible influence on the FA profile in organic and conventional milk. Palladino et al. (2010) reported differences in FA profile between Holstein Friesian and Jersey cows, with higher amounts of CLA and C15:0 in milk from Holstein Friesian cows. In our trial, despite originating from the same herd $10 \mathrm{yr}$ previously, herds genetically diverged, as reflected in the differences in breed composition, live weight, breed, and production value. Whereas the number of Jersey and Friesian cows significantly varied between the herds $(P<0.05)$, the effect of system (organic or conventional) on FA concentration was still apparent, even when the percentage of Jersey or Friesian, was used as a covariate in the analysis. In our study, whereas the genetic makeup of the organic herd contained $19 \%$ more Jersey and the conventional herd had $21 \%$ more Friesian, the majority of both herds was composed of crossbreed cows. Differences in milk FA profile has been reported between purebred Jersey and Friesen herds; however, any differences rapidly disappear in crossbreeds. Palladino et al. (2010), investigated the differences in milk FA profile between Holstein Friesian and Jersey cows, and their $\mathrm{F}_{1}$ hybrid (Jersey $\times$ Holstein). Five of the 16 FA reported were significantly different between the breeds. Milk FA profile of crossbreed and purebred cows showed even greater similarity, with only one FA (C15:0) different between Jersey and $\mathrm{F}_{1}$ hybrid, and $2 \mathrm{FA}$ (C16:0 and LnA) different between Friesian and $\mathrm{F}_{1}$ hybrid (Palladino et al., 2010). Nantapo et al. (2014) investigated milk FA profiles from Friesian, Jersey, and Friesian $\times$ Jersey cross cows and reported similar results to Palladino et al. (2010) with 5 FA significantly different between the 2 purebred lines. Only one milk FA differed between each of the purebreds and the crossbreed cows. The amount of LnA and palmitoleic acid (C16:1 cis9) varied between Friesian and crossbreed, and Jersey and crossbreed, respectively. The reported results for the amounts of C16:0, C16:1 cis-9, and LnA in milk of crossbreed cows relative to purebred Jersey or Friesian cows, however, did not agree between the 2 studies, which indicates that factors other than breed (e.g., differences in concentrate feeding) may had an influence. Both studies (Palladino et al., 2010; Nantapo et al., 2014) demonstrated that milk FA composition in purebreds differs from each other, but previous differences disappeared upon crossbreeding. We can infer that the difference in breed percentage between the herds in our study was not large enough to statistically affect milk FA profile.

\section{Effect of Season and Stage of Lactation}

Of the 51 FA analyzed, 43 were affected by the sampling date $(P<0.001)$. The New Zealand seasonal management system uses synchronous calving tied to season and pasture growth, so the stage of lactation was similar in both herds. Consequently, it is difficult to determine to what degree the differences in FA profile seen between the 2 sampling dates (spring and autumn) are due to changes in season, the progression of lactation, or the interaction of both factors. Fatty acids affected by different sampling dates were: branched-chain FA, all even-chain saturated FA except for hexanoic acid (C6:0), and all polyunsaturated FA except for arachidonic acid (C20:4n-6). The levels of the majority of de novo FA were higher in spring, except for butanoic acid (C4:0) and palmitic acid (16:0), whereas the levels of most PUFA, including LnA, CLA, and ALA, were higher in milk harvested in autumn.

Because all cows were feeding solely on pasture when milk samples were taken, changes in chemical and botanical pasture composition have to be considered when trying to explain differences between the 2 sampling dates. Pasture quality, however, was similar for both sampling periods and average BSC changed only minimally between the 2 sampling dates, being 3.7 and for 3.9 in spring and 3.6 and 3.8 in autumn for organic and conventional cows, respectively. 
No differences in chemical composition between the pastures have been found, but no detailed analysis of individual plant compounds (e.g., FA, secondary plant metabolites) has been reported. Pasture composition changes over the season (Walker et al., 2004) and the botanical composition of pastures with mixed swards is affected by varying responses of different species to grazing intervals, nutrient input, and herbage regrowth (Nie et al., 1997; Belesky et al., 1999). Differences in milk FA composition between seasons have been reported in various studies (Dunshea et al., 2008; Heck et al., 2009; Rutten et al., 2009). Larsen et al. (2012) reported a decline in ALA, LnA, and in C16:0 pasture during the milking season but found an increase for oleic acid (C18:1 cis-9). Mel'uchová et al. (2008) found ALA decreased during summer, but increased in autumn, whereas C16:0, oleic acid, and $\operatorname{LnA}$ reached their maximum concentration in summer. The differences among the studies may be due to variations in botanical composition. The concentration of long-chain unsaturated FA in milk is influenced by dietary intake of those FA by the animal. The ALA and LnA undergo hydrogenation in the rumen to yield VA, which then acts as a precursor for CLA in the mammary gland (Walker et al., 2004). A change in ALA concentration in pasture will, therefore, be reflected in CLA in milk (Mel'uchová et al., 2008). In the present study, a higher concentration for ALA and CLA in milk was found in autumn, which supports these findings.

The stage of lactation also influences the FA profile and might therefore cause some of the changes seen. Craninx et al. (2008) observed decreased FA concentration during the first 18 wk of lactation for C17:0, whereas C15:0 and C15:0 anteiso increased during this period. Kgwatalala et al. (2009) found higher amounts of C6:0, C10:0, and C12:0 and SFA in milk samples during mid-lactation (100-200 d in lactation), compared with milk samples from late lactation $(>200 \mathrm{~d}$ in lactation). Oleic acid and MUFA were significantly lower in mid-lactation compared with early and late lactation, whereas no significant difference was observed for the concentration of VA, LnA, ALA, and CLA between mid and late lactations (Kgwatalala et al., 2009). Similar trends were observed for the first 21 wk of lactation by Gross et al. (2011) with concentrations of $\mathrm{C} 8: 0, \mathrm{C} 10: 0, \mathrm{C} 12: 0$, and $\mathrm{C} 16: 0$ lower during the first 4 wk of lactation, but increasing in mid lactation (wk 17-21), whereas the reverse was seen for oleic acid (C18:1 cis-9). Stoop et al. (2009) detected the same trend for saturated and unsaturated FA and reported no change for levels of odd-chain FA (C5:0-C15:0), but saw a strong increase in C16:0 and a decrease in C18:0 during mid-lactation. Our results agree with findings by Kgwatalala et al. (2009), Stoop et al. (2009), and Gross et al. (2011) for de novo synthesized FA, which may indicate that those FA are influenced predominantly by stage of lactation rather than season. Changes in diet throughout the milking season as reported by Gross et al. (2011) have to be considered when reporting changes in concentration of de novo FA in milk. Differences in forage to concentrate ratios will change the ratio of acetate and butyrate versus propionate coming from the rumen, affecting the amount of de novo FA and protein in the milk. The pronounced increase in oleic acid levels during the first weeks of lactation, as described by $\mathrm{Kg}$ watalala et al. (2009) and Gross et al. (2011), indicated a negative energy balance and lipid mobilization from adipose tissue in high yielding animals. In our study, no difference in the concentration of oleic acid was found during different stages of lactation, suggesting that in both herds cows were able to sufficiently support their energy demands by feed intake. Dunshea et al. (2008) found no correlation for variations in concentration of VA and CLA and calving time during the year. This suggests that these FA are influenced by season rather than stage of lactation.

\section{Time of Day Effect}

Levels of 27 of the $51 \mathrm{FA}$ we quantified differed between morning and afternoon milk samples (Table 4). Even-chain saturated FA (C4:0-C16:0) were increased in morning milk, whereas higher amounts of OBCFA and VA, oleic acid, and CLA were found in milk samples collected in the afternoon. Due to differences in experimental protocols (e.g., restricted pasture access, and once a day pasture allocation) the comparability of our results with those from other trials (Loor et al., 2003) is limited.

Effects of diurnal variation and time since last milking on milk composition are not unprecedented. Some of these effects occur because chemical composition of

Table 4. Proportion of correctly grouped data assigned by discriminant function analysis ${ }^{1}$

\begin{tabular}{|c|c|c|c|c|c|c|c|c|}
\hline Group & $\begin{array}{c}\mathrm{Spr} \times \mathrm{AM} \\
\times \text { Conv }\end{array}$ & $\begin{array}{l}\mathrm{Spr} \times \mathrm{AM} \\
\quad \times \mathrm{Org}\end{array}$ & $\begin{array}{c}\mathrm{Spr} \times \mathrm{PM} \\
\times \text { Conv }\end{array}$ & $\begin{array}{c}\text { Spr } \times \text { PM } \\
\quad \times \text { Org }\end{array}$ & $\begin{array}{c}\text { Aut } \times \text { AM } \\
\times \text { Conv }\end{array}$ & $\begin{array}{l}\text { Aut } \times \text { AM } \\
\quad \times \text { Org }\end{array}$ & $\begin{array}{c}\text { Aut } \times \text { PM } \\
\times \text { Conv }\end{array}$ & $\begin{array}{c}\text { Aut } \times \text { PM } \\
\times \text { Org }\end{array}$ \\
\hline Proportion & 0.936 & 0.956 & 0.900 & 0.929 & 0.891 & 0.791 & 0.870 & 0.800 \\
\hline
\end{tabular}


pasture undergoes diurnal changes, and herbage from temperate pastures often increases in nutritional value throughout the day (Vibart et al., 2012). Dry matter and water-soluble carbohydrates (WSC) become more concentrated and accumulate over the day (Fulkerson and Donaghy, 2001; Orr et al., 2001) due to evaporation and photosynthesis (Griggs et al., 2005). Water-soluble carbohydrate content positively influences palatability (Horadagoda et al., 2009) and affects grazing behavior and rumination frequency as a consequence (Orr et al., 2001; Sun and Gibbs, 2012). Orr et al. (2001) reported a longer $(>4 \mathrm{~h})$, more continuous grazing period after afternoon milking and before sunset when dairy cows were offered a new pasture allocation compared with a shorter (2 to $3 \mathrm{~h}$ ) and more intermittent grazing period when fresh pasture was offered after morning milking. Bite mass, bite frequency, and time spent ruminating were also affected by time of pasture allocation (Orr et al., 2001), with ruminating time for cows given afternoon pasture allocation shorter than for cows that received fresh pasture after morning milking.

In our study, cows had access to fresh pasture after each milking, but differences in grazing pattern caused by diurnal changes in WSC content in pasture cannot be excluded. Differences in grazing behavior and time spent ruminating add physical influence factors such as rumen fill and rumen passage rate to the already mentioned changes in chemical composition throughout the day. Findings from Sun and Gibbs (2012) correspond readily to changes in grazing behavior reported by Orr et al. (2001). In their trial, cows which received once daily pasture allocation after afternoon milking showed a significant reduction in ruminl $\mathrm{pH}$ and OBCFA, and plant-derived PUFA in the rumen significantly increased $2 \mathrm{~h}$ after pasture allocation. Reduction in $\mathrm{pH}$ was explained by the fast intake and rapid fermentation of a large amount of DM, which overwhelmed the buffering system in the rumen as a consequence. In relation to milk composition, Loor et al. (2003) studied differences in milk FA profile for cows having limited access to pasture in the morning or afternoon while being fed TMR outside of grazing hours. Cows with access to afternoon grazing derived a larger amount of their DMI from pasture than cows which grazed in the morning, which might be a result of previously mentioned changes in WSC concentration, palatability, and consequent grazing behavior. When morning and afternoon milking were exactly $12 \mathrm{~h}$ apart, however, little variability in milk FA composition was reported (Loor et al., 2003). The only FA affected by time of milking were VA and CLA (C18:2, cis-9,trans-11), both were increased ( $P$ $<0.05)$ in milk from cows with access to pasture in the afternoon, which indicates a difference in grazing behavior depending on time of pasture allocation (Sun and Gibbs, 2012).

Besides changes in grazing behavior and WSC content, a larger effect on milk FA profile may result from differences in time since last milking, with 16 and $8 \mathrm{~h}$ since last milking for morning and afternoon milking, respectively. Despite mentioned differences in WSC content, access to fresh pasture after morning milking leads to an extended grazing period $(>2 \mathrm{~h})$, which results in a reduction in ruminal $\mathrm{pH}$ and increase in ruminal VFA (Sun and Gibbs, 2012). In addition to diurnal changes in ruminal VFA, a similar diurnal response has been reported for urea in rumen fluid, plasma, and milk (Gustafsson and Palmquist, 1993) and for the concentration of indole and skatole in milk (Lane et al., 2008). Gustafsson and Palmquist (1993) reported a time lag of 1.5 to $2.0 \mathrm{~h}$ between rumen ammonia peak and urea peak in serum, with an additional further 1 to $2 \mathrm{~h}$ between serum peak and urea peak in milk Lane et al. (2008) reported 2-fold higher amounts of indole and skatole in milk from afternoon milking compared with morning milking in cows that had grazed continuously. As indole and skatole are formed in the rumen as products from tryptophan degradation (originating from forage protein), similar diurnal changes resulting from time since last milking would not be unexpected for long-chain PUFA derived from feed and could explain differences we observed in our trial.

\section{Interactions}

In our study, only 3 out of 51 FA showed no significant interactions $(P<0$ 0.001) between at least 2 of the 3 factors considered (time of the day, season, and system). Depending on the FA, effect of system varied for different seasons and time of the day. Similarly, sampling time throughout the day had a greater or a lesser effect for individual FA during different seasons. Interactions between all 3 factors were observed for 10 FA $(P<0.001)$, including palmitic acid $(\mathrm{C} 16: 0)$, DPA, and DHA.

A PCA was conducted to achieve an overall view of the difference between the groups, considering multiple FA simultaneously. It showed that all cows within one farming system are similarly affected by season and sampling time throughout the day. Seventeen FA (C4:0, C10:0, C11:0, C12:0, C13:0, C13 iso, C14:0 iso, C15:0 iso, C15:0 anteiso, C17:0 iso, C18:0 iso, C17:1 cis-9, C18:1 trans-9, VA, LnA, C18:2 trans-10,trans-12, and $\mathrm{C} 22: 6 \mathrm{n}-3)$ were selected considering their loadings, and the PCA was performed on a matrix of 17 analytical parameters, for 354 samples. The first 8 principal components (PC) explain $89 \%$ of the total variance, whereas PC1 and PC2 describe 53\% of the total vari- 

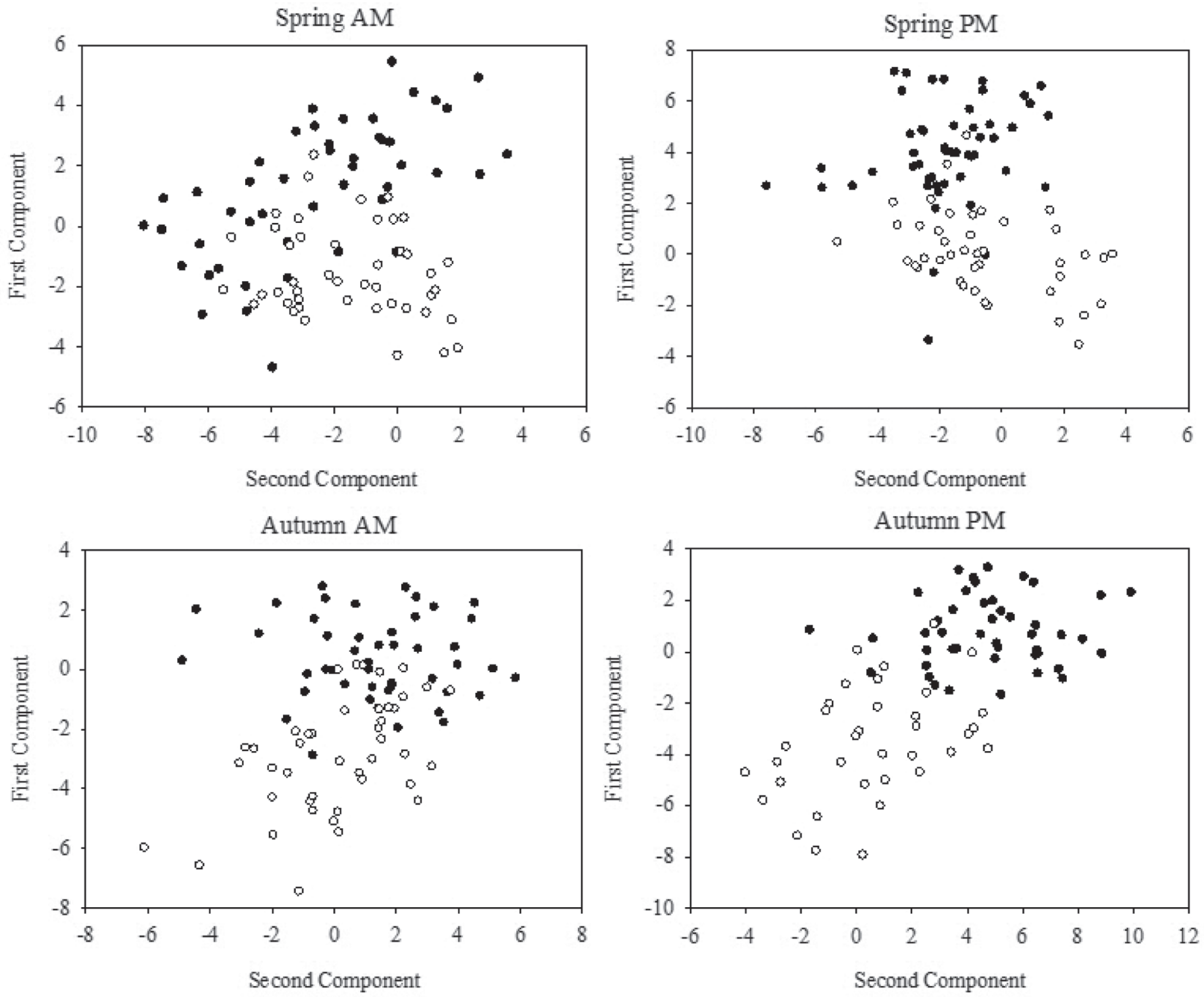

Figure 2. Principal component analysis of 8 milk sets collected, separated by season and sampling time of the day. Organic milk is represented by $(\bigcirc)$ and conventional milk by $(\bullet)$.

ance. The FA accounting for most variation in the PCA were C10:0 and C14:0 iso (positive loading) and C13:0 and LnA (negative loading) for PC1 and PC2, respectively. For better visibility the PCA results were divided into 4 individual plots: spring AM, spring PM, autumn AM, and autumn PM (Figure 2).

Discriminant function analysis was performed using 8 classes of data grouped by system $\times$ season $\times$ time to define a set of discriminant functions. The data was then re-evaluated using the discriminant functions to assign them the closest group and the proportion of correctly and misassigned data determined (Table 4), with the same $17 \mathrm{FA}$ chosen as predictors. The same predictors were also used to classify the samples into
2 groups with $95 \%$ correctly assigned into organic or conventional milk, and 96\% correctly assigned into spring or autumn, respectively. The FA accounting for the most variation between the groups were C13:0 iso and C18:0 iso (positive loading) and C11:0 and C14:0 iso (negative loading) for the first and the second variate, respectively.

In our trial, it is, therefore, possible to discriminate between organic and conventionally produced milk. Further research is necessary to determine whether the same discriminant functions can be applied to other sets of organic and conventionally produced milk.

Discussion on interactions among factors (system, season, and time of milking) is purely speculative be- 

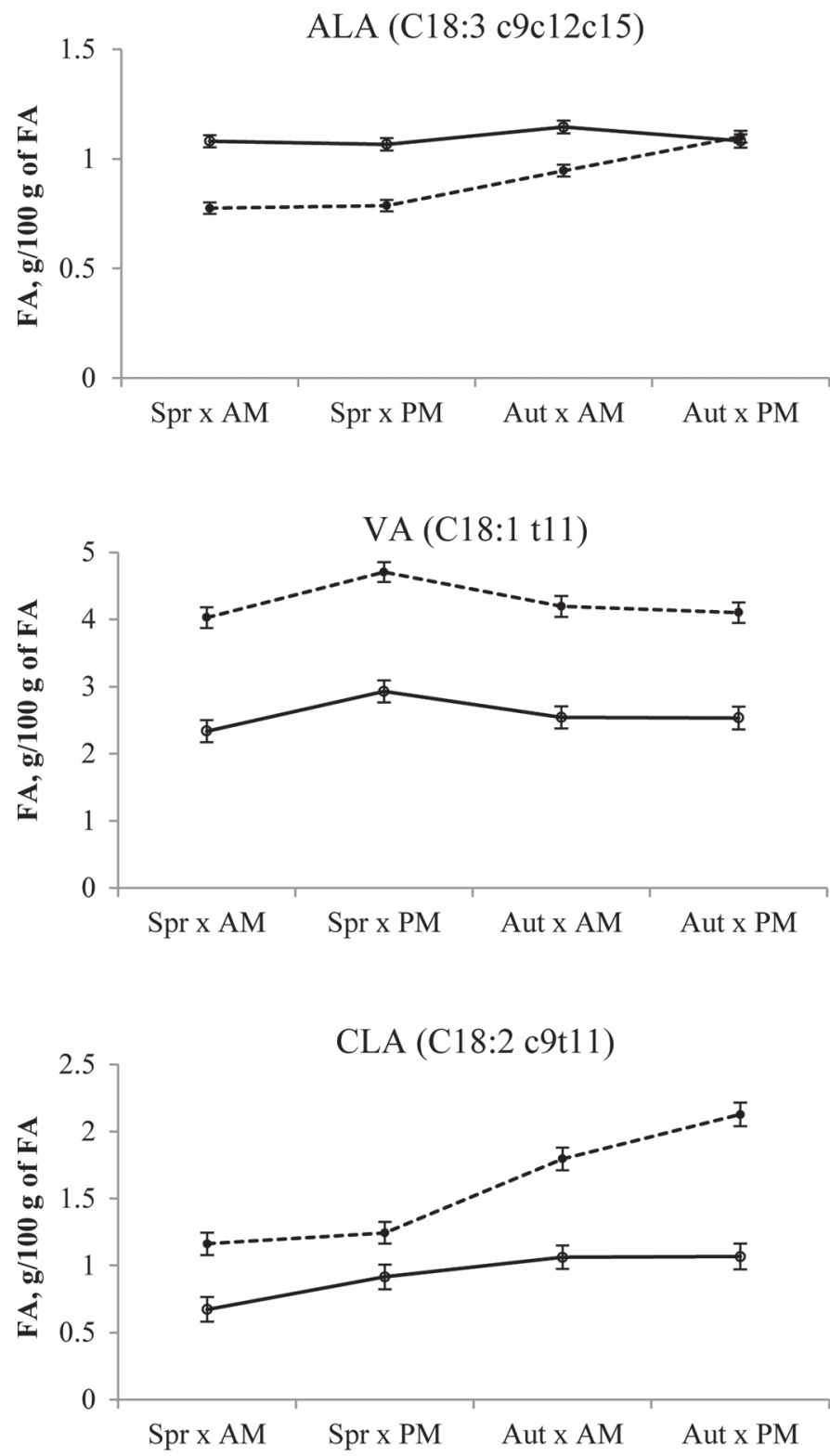

Figure 3. Interactions of $\alpha$-linolenic acid (ALA), vaccenic acid (VA), and CLA concentration on sampling time for each system. Organic milk is represented by (-O-) and conventional milk by (- - - ). $\mathrm{c}=$ cis; $\mathrm{t}=$ trans; $\mathrm{ALA}=\alpha$-linolenic acid; $\mathrm{VA}=$ vaccenic acid.

cause not enough is known on the effect each individual factor alone. Our study excluded a large number of known influence factors, but still the drivers of reported differences in milk FA for each remaining factor is not known with certainty. It cannot be assumed either that the effect of 2 or more factors (system, season, and time of milking) is equal to the sum of each individual effect. No pattern or trend could be identified in our study, and interpretation of the multitude of different interactions is complicated by the lack of understanding of the causes. The effect of interactions has to be explained for each individual FA to be put into wider context of changes in milk FA profile.

Taking ALA, VA, and CLA, as examples (Figure 3), only ALA and CLA showed a 3-way interaction between system, season, and time of milking. The ALA was higher in organic milk throughout the first 3 time points $(\mathrm{Spr} \times \mathrm{AM}, \mathrm{Spr} \times \mathrm{PM}$, Aut $\times \mathrm{AM})$, whereas in conventional milk ALA was significantly increased in Aut $\times$ AM and was even greater in Aut $\times$ PM, compared with spring. The VA was significantly higher in conventional milk throughout all sampling points with concentrations showing the same trend for organic and conventional milk, with an increase in Spr $\times$ PM. The concentration of CLA in conventional milk was, similar to VA, higher than organic milk through all sampling points, with a marked increase in Aut $\times \mathrm{AM}$ and a further increase in Aut $\times$ PM. In organic milk CLA levels were relatively constant, except for a lower concentration in Spr $\times$ AM. A noticeable similarity was present in concentration changes between ALA and CLA over the 4 sampling points within each system.

Although we can only speculate, significantly higher levels of VA and CLA in conventional milk may be related to greater amounts of $\mathrm{N}$ fertilizer applied to conventional pastures. Presumably, this could have resulted in higher amounts of ALA in the conventional pasture (as discussed above under "System Effect"). The fact that VA showed the same trend in organic and conventional milk leads us to speculate that in our study, apart from dietary intake of ALA, no other major influence factors on VA are present in milk. In addition, because VA is the major precursor of CLA in the mammary gland, an overall greater amount of CLA in conventional milk is equally linked to a higher amount $\mathrm{N}$ fertilizer. The CLA and ALA showed an increase in autumn compared with spring sampling, which was more marked in conventional milk as well. Differences in concentration between sampling months can be related to a combination of interdependent factors [e.g., changes in stage of lactation, $\Delta^{9}$-desaturase activity (Heck, 2009), and FA composition in feed (Khiaosa-Ard et al., 2010)]. Further investigation would be necessary to quantify the specific effect of each of these factors on the FA profile.

\section{CONCLUSIONS}

The present study indicated that in a system where many of the factors known to influence milk FA composition have been controlled, differences between organic and conventional milk samples can still be found. Several possible causes for variation in FA profile were discussed, and some were excluded (e.g., fish oil supple- 
mentation of the organic herd, and differences in botanical composition). The influence of several other factors, among them application rate of $\mathrm{N}$ fertilizer on pasture, time between milking, and time between main feeding time and milking, requires further investigation to determine their effects on milk FA profile. Future studies on milk FA profile will also benefit from consideration of the FA composition of pasture and ruminal fluid. In addition, our results showed how much variation in FA profile in each milk sample can be accounted for by sampling time throughout the day and throughout the year. This will help to understand some of the variation across results presented in different studies comparing organic and conventional milk FA.

\section{ACKNOWLEDGMENTS}

This work was funded by grants from Fonterra Cooperative Group Limited (New Zealand), Ministry of Science and Innovation (New Zealand), and the Agricultural and Marketing Research and Development Trust (AGMARDT; New Zealand). The authors also express their sincere appreciation to Joy Dick (AgResearch, Palmerston North, New Zealand) for her assistance in locating reference material.

\section{REFERENCES}

Arvidsson, K., A. M. Gustavsson, V. Fievez, and K. Martinsson. 2012. The effect of $\mathrm{N}$-fertilisation rate or inclusion of red clover to timothy leys on fatty acid composition in milk of dairy cows fed a commercial silage: concentrate ratio. Animal 6:1178-1186.

Baars, T., J. Wohlers, D. Kusche, and G. Jahreis. 2012. Experimental improvement of cow milk fatty acid composition in organic winter diets. J. Sci. Food Agric. 92:2883-2890. http://dx.doi. org/10.1002/jsfa.5525.

Belesky, D. P., J. M. Fedders, K. E. Turner, and J. M. Ruckle. 1999. Productivity, botanical composition, and nutritive value of swards including forage chicory. Agron. J. 91:450-456.

Bharathan, M., D. J. Schingoethe, A. R. Hippen, K. F. Kalscheur, M. L. Gibson, and K. Karges. 2008. Conjugated linoleic acid increases in milk from cows fed condensed corn distillers solubles and fish oil. J. Dairy Sci. 91:2796-2807. http://dx.doi.org/10.3168/ jds.2007-0938.

Bochi-Brum, O., R. García, R. Bodas, A. Calleja, S. Andrés, and S. López. 2011. Nutritive value of herbage from mountain hay meadow managed under traditional and intensive harvest systems as affected by nitrogen fertilisation and time of cutting. Anim. Prod. Sci. 51:549-556.

Bolland, M. D. A., and I. F. Guthridge. 2007. Responses of intensively grazed dairy pastures to applications of fertiliser nitrogen in south-western Australia. Aust. J. Exp. Agric. 47:927-941. http:// dx.doi.org/10.1071/ea0601410.1016/0377-8401(88)90044-2.

Boufaïed, H., P. Y. Chouinard, G. F. Tremblay, H. V. Petit, R. Michaud, and G. Bélanger. 2003. Fatty acids in forages. I. Factors affecting concentrations. Can. J. Anim. Sci. 83:501-511.

Busquet, M., S. Calsamiglia, A. Ferret, P. W. Cardozo, and C. Kamel. 2005. Effects of cinnamaldehyde and garlic oil on rumen microbial fermentation in a dual flow continuous culture. J. Dairy Sci. 88:2508-2516.

Calsamiglia, S., M. Busquet, P. W. Cardozo, L. Castillejos, and A. Ferret. 2007. Invited review: Essential oils as modifiers of rumen mi- crobial fermentation. J. Dairy Sci. 90:2580-2595. http://dx.doi. org $/ 10.3168 /$ jds.2006-644.

Cardozo, P. W., S. Calsamiglia, A. Ferret, and C. Kamel. 2004. Effects of natural plant extracts on ruminal protein degradation and fermentation profiles in continuous culture. J. Anim. Sci. $82: 3230-3236$.

Collomb, M., W. Bisig, U. Buetikofer, R. Sieber, M. Bregy, and L. Etter. 2008. Fatty acid composition of mountain milk from Switzerland: Comparison of organic and integrated farming systems. Int. Dairy J. 18:976-982.

Coppa, M., A. Ferlay, C. Chassaing, C. Agabriel, F. Glasser, Y. Chilliard, G. Borreani, R. Barcarolo, T. Baars, D. Kusche, O. M. Harstad, J. Verbič, J. Golecký, and B. Martin. 2013. Prediction of bulk milk fatty acid composition based on farming practices collected through on-farm surveys. J. Dairy Sci. 96:4197-4211. http://dx.doi.org/10.3168/jds.2012-6379.

Coppa, M., A. Ferlay, F. Monsallier, I. Verdier-Metz, P. Pradel, R. Didienne, A. Farruggia, M. C. Montel, and B. Martin. 2011. Milk fatty acid composition and cheese texture and appearance from cows fed hay or different grazing systems on upland pastures. J. Dairy Sci. 94:1132-1145. http://dx.doi.org/10.3168/jds.2010-3510.

Craninx, M., A. Steen, H. Van Laar, T. Van Nespen, J. Martin-Tereso, B. De Baets, and V. Fievez. 2008. Effect of lactation stage on the odd- and branched-chain milk fatty acids of dairy cattle under grazing and indoor conditions. J. Dairy Sci. 91:2662-2677. http://dx.doi.org/10.3168/jds.2007-0656.

Croissant, A. E., S. P. Washburn, L. L. Dean, and M. A. Drake. 2007. Chemical properties and consumer perception of fluid milk from conventional and pasture-based production systems. J. Dairy Sci. 90:4942-4953.

Destaillats, F., M. de Wispelaere, F. Joffre, P. A. Golay, B. Hug, F. Giuffrida, L. Fauconnot, and F. Dionisi. 2006. Authenticity of milk fat by fast analysis of triacylglycerols. Application to the detection of partially hydrogenated vegetable oils. J. Chromatogr. A 1131:227-234. http://dx.doi.org/10.1016/j.chroma.2006.07.040.

Dewhurst, R. J., N. D. Scollan, S. J. Youell, J. K. S. Tweed, and M. O. Humphreys. 2001. Influence of species, cutting date and cutting interval on the fatty acid composition of grasses. Grass Forage Sci. 56:68-74

Donovan, D. C., D. J. Schingoethe, R. J. Baer, J. Ryali, A. R. Hippen, and S. T. Franklin. 2000. Influence of dietary fish oil on conjugated linoleic acid and other fatty acids in milk fat from lactating dairy cows. J. Dairy Sci. 83:2620-2628.

Dunshea, F. R., G. P. Walker, E. Ostrowska, and P. T. Doyle. 2008. Seasonal variation in the concentrations of conjugated linoleic and trans fatty acids in milk fat from commercial dairy farms is associated with pasture and grazing management and supplementary feeding practices. Aust. J. Exp. Agric. 48:1062-1075. http:// dx.doi.org/10.1071/ea07286.

Elgersma, A., P. Maudet, I. M. Witkowska, and A. C. Wever. 2005. Effects of nitrogen fertilisation and regrowth period on fatty acid concentrations in perennial ryegrass (Lolium perenne L.). Ann. Appl. Biol. 147:145-152.

Ellis, K. A., G. Innocent, D. Grove-White, P. Cripps, W. G. McLean, C. V. Howard, and M. Mihm. 2006. Comparing the fatty acid composition of organic and conventional milk. J. Dairy Sci. 89:19381950.

Falchero, L., G. Lombardi, A. Gorlier, M. Lonati, M. Odoardi, and A. Cavallero. 2010. Variation in fatty acid composition of milk and cheese from cows grazed on two alpine pastures. Dairy Sci. Technol. 90:657-672. http://dx.doi.org/10.1051/dst/2010035.

Fall, N., K. Forslund, and U. Emanuelson. 2008. Reproductive performance, general health, and longevity of dairy cows at a Swedish research farm with both organic and conventional production. Livest. Sci. 118:11-19. http://dx.doi.org/10.1016/j.livsci.2008.01.017.

Feldberg, R. S., S. C. Chang, A. N. Kotik, M. Nadler, Z. Neuwirth, D. C. Sundstrom, and N. H. Thompson. 1988. In vitro mechanism of inhibition of bacterial cell growth by allicin. Antimicrob. Agents Chemother. 32:1763-1768.

French, E. A., S. J. Bertics, and L. E. Armentano. 2012. Rumen and milk odd- and branched-chain fatty acid proportions are minimally 
influenced by ruminal volatile fatty acid infusions. J. Dairy Sci. 95:2015-2026. http://dx.doi.org/10.3168/jds.2011-4827.

Fulkerson, W. J., and D. J. Donaghy. 2001. Plant-soluble carbohydrate reserves and senescence-Key criteria for developing an effective grazing management system for ryegrass-based pastures: A review. Aust. J. Exp. Agric. 41:261-275. http://dx.doi.org/10.1071/ ea00062.

Glasser, F., M. Doreau, G. Maxin, and R. Baumont. 2013. Fat and fatty acid content and composition of forages: A meta-analysis. Anim. Feed Sci. Technol. 185:19-34.

Gorlier, A., M. Lonati, M. Renna, C. Lussiana, G. Lombardi, and L. M. Battaglini. 2013. Changes in pasture and cow milk compositions during a summer transhumance in the western Italian Alps. J. Appl. Botany Food Qual. 85:216-223.

Griggs, T. C., J. W. MacAdam, H. F. Mayland, and J. C. Burns. 2005. Nonstructural carbohydrate and digestibility patterns in orchardgrass swards during daily defoliation sequences initiated in evening and morning. Crop Sci. 45:1295-1304. http://dx.doi. org/10.2135/cropsci2003.0613.

Gross, J., H. A. Van Dorland, R. M. Bruckmaier, and F. J. Schwarz. 2011. Milk fatty acid profile related to energy balance in dairy cows. J. Dairy Res. 78:479-488. http://dx.doi.org/10.1017/ S0022029911000550.

Gustafsson, A. H., and D. L. Palmquist. 1993. Diurnal variation of rumen ammonia, serum urea, and milk urea in dairy cows at high and low yields. J. Dairy Sci. 76:475-484.

Härtig, C. 2008. Rapid identification of fatty acid methyl esters using a multidimensional gas chromatography-mass spectrometry database. J. Chromatogr. A 1177:159-169. http://dx.doi. org/10.1016/j.chroma.2007.10.089.

Heck, J. M. L., H. J. F. van valenberg, J. Dijkstra, and A. C. M van Hooijdonk. 2009. Seasonal variation in the Dutch bovine raw milk composition. J. Dairy Sci. 92:4745-4755. http://dx.doi. org/10.3168/jds.2009-2146.

Horadagoda, A., W. J. Fulkerson, K. S. Nandra, and I. M. Barchia. 2009. Grazing preferences by dairy cows for 14 forage species. Anim. Prod. Sci. 49:586-594. http://dx.doi.org/10.1017/ S002185969800584.

Huws, S. A., M. R. F. Lee, S. M. Muetzel, M. B. Scott, R. J. Wallace, and N. D. Scollan. 2010. Forage type and fish oil cause shifts in rumen bacterial diversity. FEMS Microbiol. Ecol. 73:396-407. http://dx.doi.org/10.1111/j.1574-6941.2010.00892.x.

Jarzomski, C. M., N. E. Stamp, and M. D. Bowers. 2000. Effects of plant phenology, nutrients and herbivory on growth and defensive chemistry of plantain, Plantago lanceolata. Oikos 88:371-379.

Kamleh, R., J. Fanni, and E. El Mayda. 2010. The characteristics of cow's milkfat produced in four different dairy regions in Bekaa Valley (Lebanon). J. Food Agric. Environ. 8:182-185.

Kelly, T., N. Butcher, K. Harrington, C. Holmes, D. Horne, P. Kemp, A. Palmer, A. Quinn, N. Shadbolt, and A. Thatcher. 2005. Organic-conventional dairy systems trial in New Zealand: four years' results. Pages 268-271 in Researching sustainable systems. Proceedings of the First Scientific Conference of the International Society of Organic Agriculture Research (ISOFAR), held in Cooperation with the International Federation of Organic Agriculture Movements (IFOAM) and the National Association for Sustainable Agriculture, Australia (NASAA), Adelaide Convention Centre, Adelaide, South Australia, 21-23 September, 2005. U. Kopke, U. Niggli, D. Neuhoff, P. Cornish, W. Lockeretz, and H. Willer, ed. International Society of Organic Agricultural Research (ISOFAR), Bonn, Germany.

Kgwatalala, P. M., E. M. Ibeagha-Awemu, A. F. Mustafa, and X. Zhao. 2009. Stearoyl-CoA desaturase 1 genotype and stage of lactation influences milk fatty acid composition of Canadian Holstein cows. Anim. Genet. 40:609-615. http://dx.doi.org/10.1111/ j.1365-2052.2009.01887.x.

Khiaosa-Ard, R., F. Klevenhusen, C. R. Soliva, M. Kreuzer, and F. Leiber. 2010. Transfer of linoleic and linolenic acid from feed to milk in cows fed isoenergetic diets differing in proportion and origin of concentrates and roughages. J. Dairy Res. 77:331-336. http://dx.doi.org/10.1017/S0022029910000257.
Kusche, D., K. Ruebesam, and T. Baars. 2010. Fatty acids and antioxidant profiles in summer milk from different biodynamic and conventional systems in Southern Germany. (Grassland Science in Europe, Volume 15). H. Schnyder, J. Isselstein, F. Taube, K. Auerswald, J. Schellberg, M. Wachendorf, A. Herrmann, M. Gierus, N. Wrage, and A. Hopkins, ed. Mecke Druck und Verlag, Duderstadt, Germany.

Lambert, M. G., D. A. Clark, D. A. Grant, D. A. Costall, and Y. S. Gray. 1986. Infuence of fertiliser and grazing management on North Island moist hill country. 4. Pasture species abundance. N. Z. J. Agric. Res. 29:23-31.

Lane, G. A., K. Fraser, M. Yu, D. Pacheco, D. E. Dalley, and L. A. Hofmann. 2008. BRIEF COMMUNICATION: Effect of once daily milking on milk flavour chemistry. Proc. N. Z. Soc. Anim. Prod. $68: 162-163$

Larsen, M. K., X. C. Fretté, T. Kristensen, J. Eriksen, K. Søegaard, and J. H. Nielsen. 2012. Fatty acid, tocopherol and carotenoid content in herbage and milk affected by sward composition and season of grazing. J. Sci. Food Agric. 92:2891-2898. http://dx.doi. org $/ 10.1002 /$ jsfa. 5620

Lee, Y. J., and T. C. Jenkins. 2011. Biohydrogenation of linolenic acid to stearic acid by the rumen microbial population yields multiple intermediate conjugated diene isomers. J. Nutr. 141:1445-1450.

Leiber, F., M. Kreuzer, D. Nigg, H. R. Wettstein, and M. R. L. Scheeder. 2005. A study on the causes for the elevated n-3 fatty acids in cows' milk of alpine origin. Lipids 40:191-202. http://dx.doi. org/10.1007/s11745-005-1375-3.

Lindmark Månsson, H. 2008. Fatty acids in bovine milk fat. Food Nutr. Res. 52: http://dx.doi.org/10.3402/fnr.v52i0.1821.

Loor, J. J., F. D. Soriano, X. Lin, J. H. Herbein, and C. E. Polan. 2003. Grazing allowance after the morning or afternoon milking for lactating cows fed a total mixed ration (TMR) enhances trans 11-18:1 and cis9, trans 11-18:2 (rumenic acid) in milk fat to different extents. Anim. Feed Sci. Technol. 109:105-119. http://dx.doi. org/10.1016/s0377-8401(03)00175-5.

Lourenco, M., G. Van Ranst, B. Vlaeminck, S. De Smet, and V. Fievez. 2008. Influence of different dietary forages on the fatty acid composition of rumen digesta as well as ruminant meat and milk. Anim. Feed Sci. Technol. 145:418-437. http://dx.doi. org/10.1016/j.anifeedsci.2007.05.043.

Mackle, T. R., C. R. Parr, and A. M. Bryant. 1996. Nitrogen fertiliser effects on milk yield and composition, pasture intake, nitrogen and energy partitioning, and rumen fermentation parameters of dairy cows in early lactation. N. Z. J. Agric. Res. 39:341-356.

Maurice-Van Eijndhoven, M. H. T. S. J. Hiemstra, and M. P. L. Calus. 2011. Short communication: Milk fat composition of 4 cattle breeds in the Netherlands. J. Dairy Sci. 94:1021-1025. http:// dx.doi.org/10.3168/jds.2009-3018.

McKenzie, F. R., J. L. Jacobs, M. J. Ryan, and G. Kearney. 1999 Effect of rate and time of nitrogen application from autumn to midwinter on perennial ryegrass-white clover dairy pastures in western Victoria. 2. Pasture nutritive value. Aust. J. Agric. Res. 50:1067-1072. http://dx.doi.org/10.1071/ar98197.

Mel’uchová, B., J. Blaško, R. Kubinec, R. Górová, J. Dubravská, M. Margetín, and L. Soják. 2008. Seasonal variations in fatty acid composition of pasture forage plants and CLA content in ewe milk fat. Small Rumin. Res. 78:56-65.

Moate, P. J., S. R. O. Williams, M. C. Hannah, R. J. Eckard, M. J. Auldist, B. E. Ribaux, J. L. Jacobs, and W. J. Wales. 2013. Effects of feeding algal meal high in docosahexaenoic acid on feed intake, milk production, and methane emissions in dairy cows. J. Dairy Sci. 96:3177-3188.

Molan, A. L.. A. J. Duncan, T. N. Barry, and W. C. McNabb. 2003. Effects of condensed tannins and crude sesquiterpene lactones extracted from chicory on the motility of larvae of deer lungworm and gastrointestinal nematodes. Parasitol. Int. 52:209-218.

Moorby, J. M., M. R. F. Lee, D. R. Davies, E. J. Kim, G. R. Nute, N. M. Ellis, and N. D. Scollan. 2009. Assessment of dietary ratios of red clover and grass silages on milk production and milk quality in dairy cows. J. Dairy Sci. 92:1148-1160. http://dx.doi org/10.3168/jds.2008-1771. 
Nantapo, C. T. W., V. Muchenje, and A. Hugo. 2014. Atherogenicity index and health-related fatty acids in different stages of lactation from Friesian, Jersey and Friesian $\times$ Jersey cross cow milk under a pasture-based dairy system. Food Chem. 146:127-133.

Nie, Z. N., A. D. Mackay, D. J. Barker, I. Valentine, and J. Hodgson. 1997. Changes in plant population density, composition and sward structure of a hill pasture during a pastoral fallow. Grass Forage Sci. 52:190-198.

Orr, R. J., S. M. Rutter, P. D. Penning, and A. J. Rook. 2001. Matching grass supply to grazing patterns for dairy cows. Grass Forage Sci. 56:352-361.

Osborne, V. R., S. Radhakrishnan, N. E. Odongo, A. R. Hill, and B. W. McBride. 2008. Effects of supplementing fish oil in the drinking water of dairy cows on production performance and milk fatty acid composition. J. Anim. Sci. 86:720-729. http://dx.doi. org/10.2527/jas.2007-0342.

Ozturk, A., Y. Ozdemir, and Z. Goksel. 2009. Apple vinegar and its therapeutic effects. TABAD. Tarim Bilimleri Arastirma Dergisi $2: 155-158$.

Palladino, R. A., F. Buckley, R. Prendiville, J. J. Murphy, J. Callan, and D. A. Kenny. 2010. A comparison between Holstein-Friesian and Jersey dairy cows and their F1 hybrid on milk fatty acid composition under grazing conditions. J. Dairy Sci. 93:2176-2184.

Patra, A. K., and J. Saxena. 2011. Exploitation of dietary tannins to improve rumen metabolism and ruminant nutrition. J. Sci. Food Agric. 91:24-37. http://dx.doi.org/10.1002/jsfa.4152.

Petersen, M. B., K. Søegaard, and S. K. Jensen. 2011. Herb feeding increases n-3 and n-6 fatty acids in cow milk. Livest. Sci. 141:90-94. http://dx.doi.org/10.1016/j.livsci.2011.05.004.

Rutten, M. J. M., H. Bovenhuis, K. A. Hettinga, H. J. F. van Valenberg, and J. A. M. van Arendonk. 2009. Predicting bovine milk fat composition using infrared spectroscopy based on milk samples collected in winter and summer. J. Dairy Sci. 92:6202-6209. http://dx.doi.org/10.3168/jds.2009-2456.

Slots, T., G. Butler, C. Leifert, T. Kristensen, L. H. Skibsted, and J. H. Nielsen. 2009. Potentials to differentiate milk composition by different feeding strategies. J. Dairy Sci. 92:2057-2066. http:// dx.doi.org/10.3168/jds.2008-1392.
Soyeurt, H., P. Dardenne, F. Dehareng, C. Bastin, and N. Gengler. 2008. Genetic parameters of saturated and monounsaturated fatty acid content and the ratio of saturated to unsaturated fatty acids in bovine milk. J. Dairy Sci. 91:3611-3626. http://dx.doi. org/10.3168/jds.2007-0971.

Stoop, W. M., H. Bovenhuis, J. M. L. Heck, and J. A. M. van Arendonk. 2009. Effect of lactation stage and energy status on milk fat composition of Holstein-Friesian cows. J. Dairy Sci. 92:14691478. http://dx.doi.org/10.3168/jds.2008-1468.

Sun, X. Q., and S. J. Gibbs. 2012. Diurnal variation in fatty acid profiles in rumen digesta from dairy cows grazing high-quality pasture. Anim. Feed Sci. Technol. 177:152-160.

Toledo, P., A. Andrén, and L. Björck. 2002. Composition of raw milk from sustainable production systems. Int. Dairy J. 12:75-80. http://dx.doi.org/10.1016/s0958-6946(01)00148-0.

Vanhatalo, A., K. Kuoppala, V. Toivonen, and K. J. Shingfield. 2007. Effects of forage species and stage of maturity on bovine milk fatty acid composition. Eur. J. Lipid Sci. Technol. 109:856-867.

Vibart, R. E., D. Pacheco, K. Lowe, and B. A. Barrett. 2012. The effects of time of allocation of a ryegrass-based pasture on animal performance, nitrogen utilization and grazing behavior from latelactation dairy cows. J. Dairy Sci. 95(Suppl. 2):727. (Abstr.)

Vlaeminck, B., V. Fievez, A. R. J. Cabrita, A. J. M. Fonseca, and R. J. Dewhurst. 2006. Factors affecting odd- and branched-chain fatty acids in milk: A review. Anim. Feed Sci. Technol. 131:389-417. http://dx.doi.org/10.1016/j.anifeedsci.2006.06.017.

Walker, G. P., F. R. Dunshea, and P. T. Doyle. 2004. Effects of nutrition and management on the production and composition of milk fat and protein: A review. Aust. J. Agric. Res. 55:1009-1028.

Wiking, L., P. K. Theil, J. H. Nielsen, and M. T. Sørensen. 2010. Effect of grazing fresh legumes or feeding silage on fatty acids and enzymes involved in the synthesis of milk fat in dairy cows. J. Dairy Res. 77:337-342. http://dx.doi.org/10.1017/S002202991000021X.

Woodford, S. T., and M. R. Murphy. 1988. Effect of forage physical form on chewing activity, dry matter intake, and rumen function of dairy cows in early lactation. J. Dairy Sci. 71:674-686. 